\title{
FOTOGRAFICKÁ P̌̌ÍLOHA
}

\section{Dokumentární fotografie z období 1. světové války}

\author{
JINDŘICH BIŠICKÝ (1889-1949), K VYDÁNÍ PŘIPRAVIL BOHUSLAV ŠALANDA
}

\section{Documentary Photos of World War I}

\begin{abstract}
The collection of photographs presents a brief history of World War I at eastern and southern front. The author of these pictures, Jindřich Bišický (18891949), was an official photographer of the 47th regiment of c.k. Austrian-Hungarian army during his military journey to Galicia, Bukovina as well as the southern Alps. He portrayed a daily life of soldiers also outside the direct battle actions. Further, the collection includes the evidence of lifestyle at the areas affected by war. For instance, pictures 24 and 26 preserve the memory of inhabitants living in Shtetl Delatyn who, with minor losses, survived World War I. It is however horrible that on July 1, 1941 the German army occupied Delatyn and on October 16, 1941 about 1950 Jews from this Shtetl were murdered in the forest outside the town and buried in three mass graves.
\end{abstract}

Keywords: World War I, Galicia, Bukovina, southern Alps, daily life of soldiers

1. Jindřich Bišický vyvolává z negativi̊ fotografie kontaktni metodou.

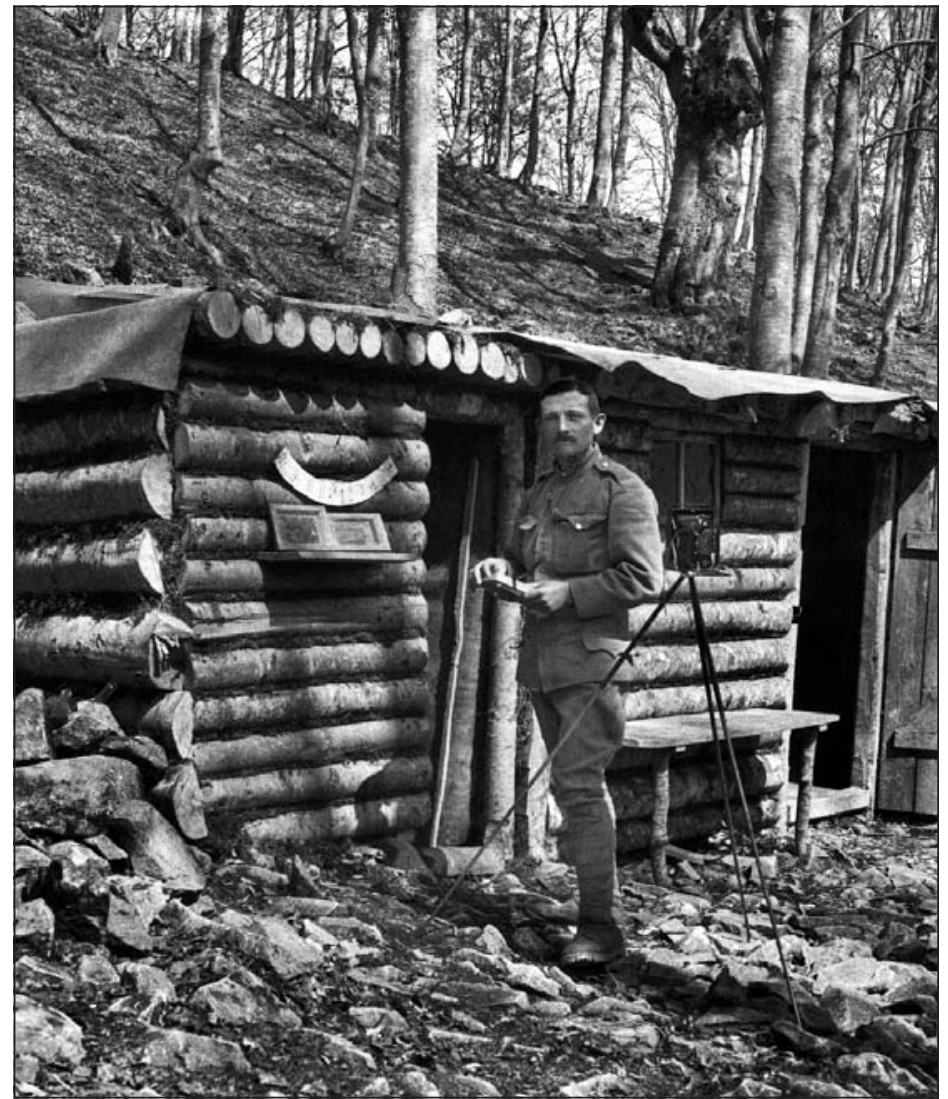




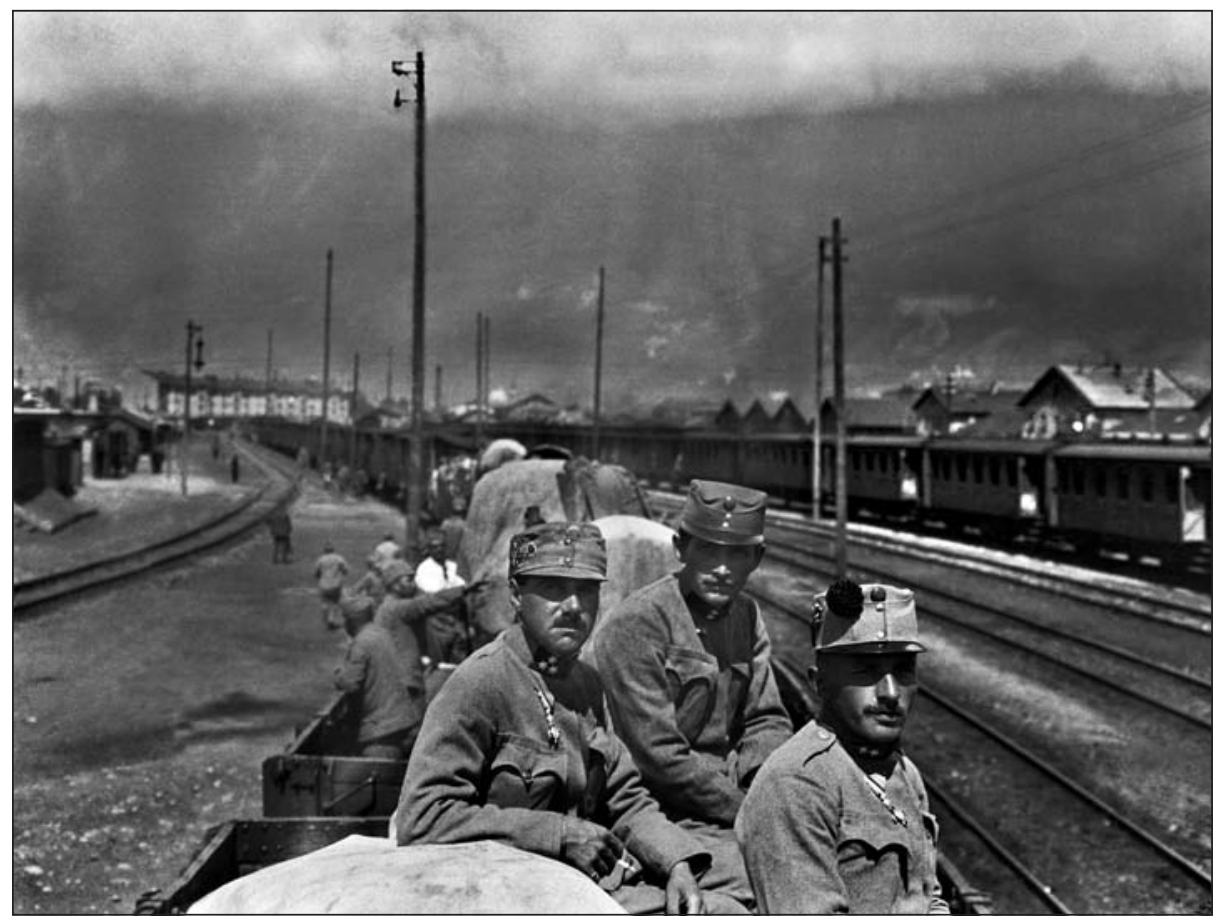

2. Důstojnický sbor přepravován železnicí ze sočské fronty (14. březen 1916). Autor snímků uprostřed.

3. Nakládání trénu na vagóny ve stanici Pergina v Tyrolích (26. červen 1918).

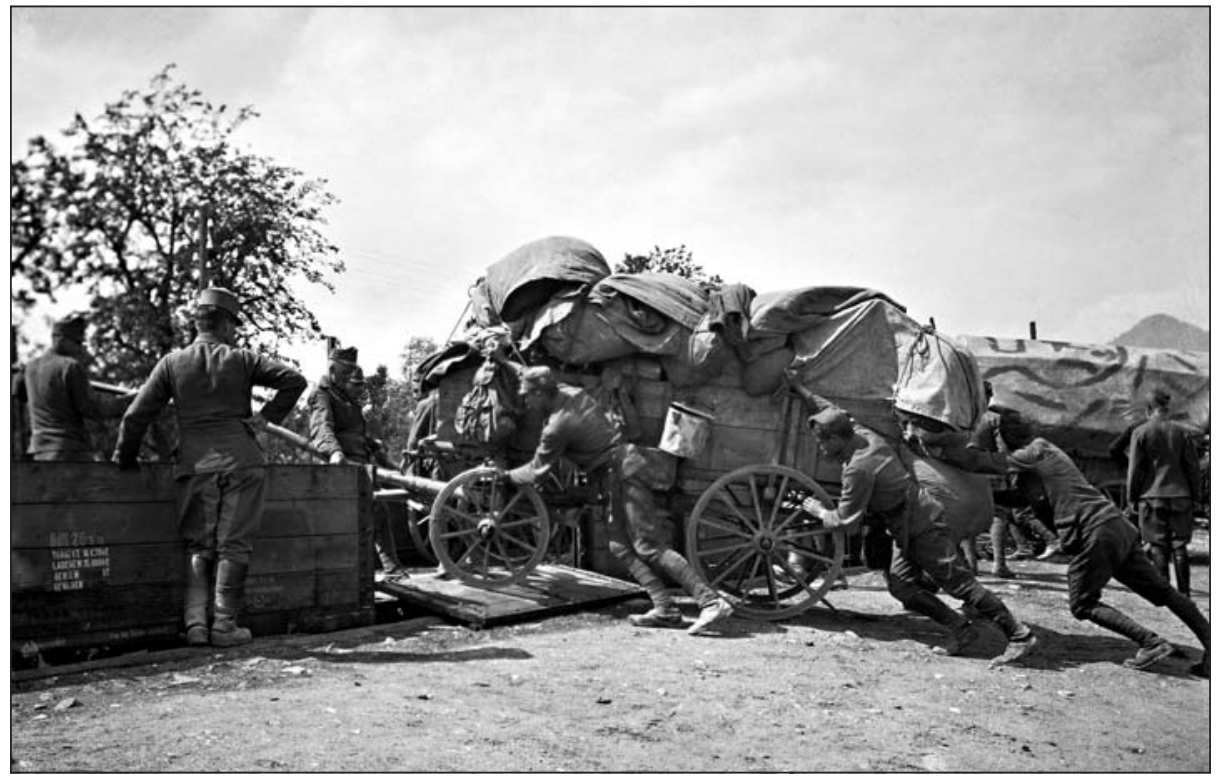




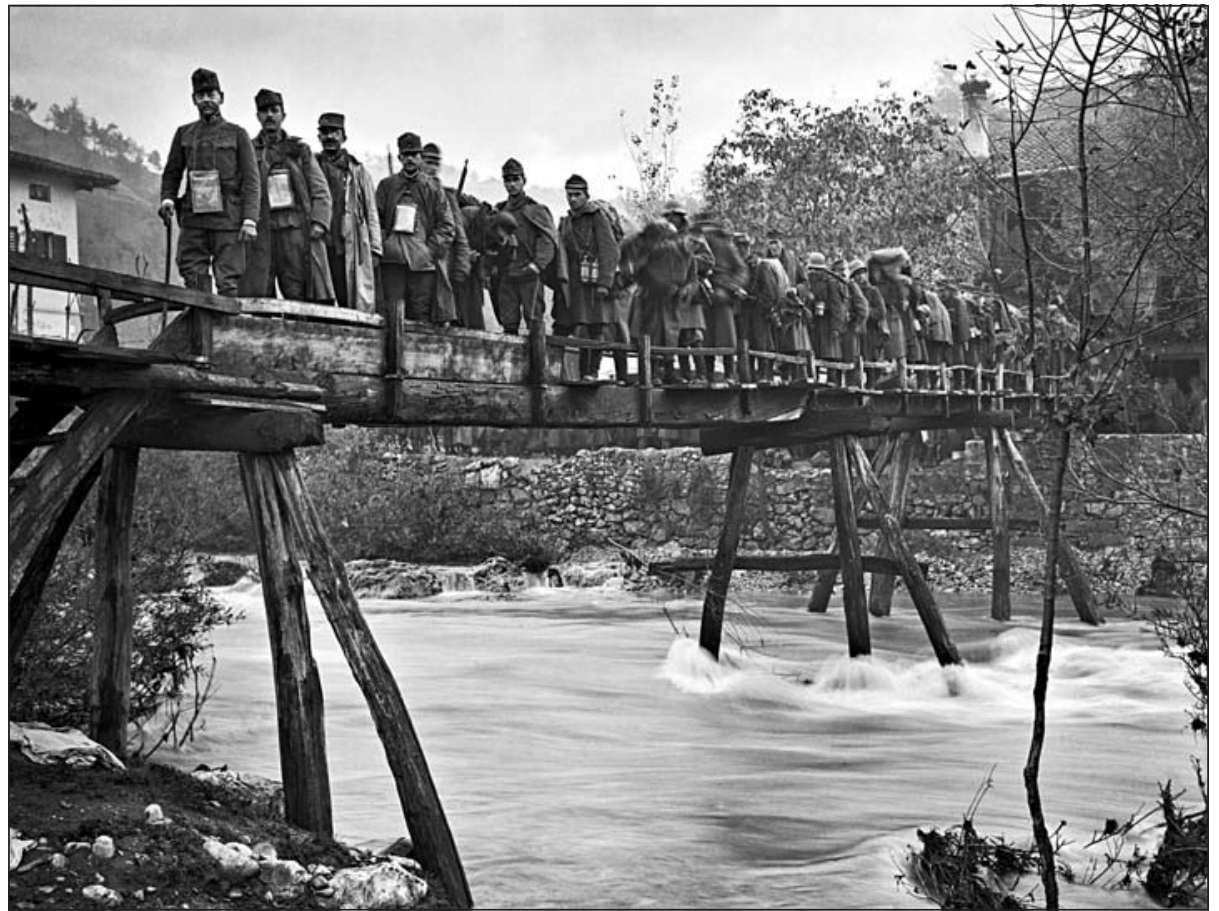

4. Štáb 47. pěšího regimentu při přechodu hraniční říčky Jurido u Mernika kolem 8. hodiny (29. ř́jen 1917).

5. Pevnost Campologno, zničená rakouskou dělostřeleckou baterií dvou hmoždiřủ Škoda ráže 30,5 cm (24. květen 1916).

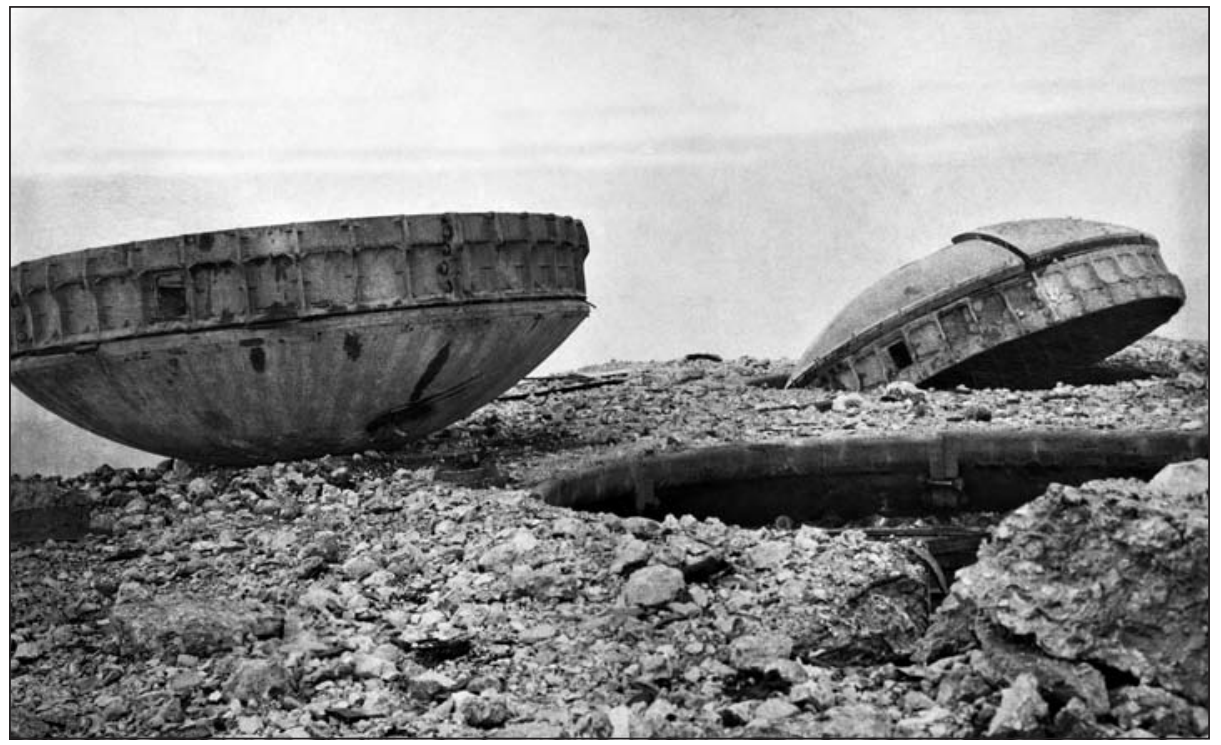




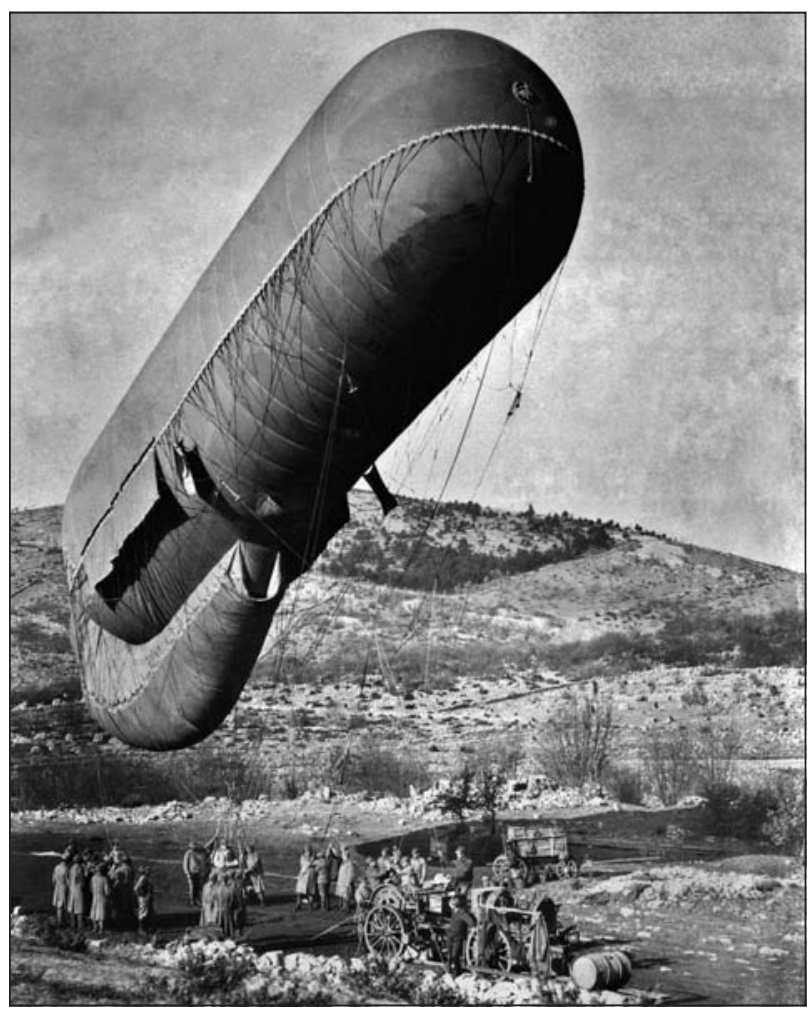

6. Vypouštění upoutaného pozorovacího balonu u Rasíkové v Haliči (zárí 1915).

7. Těžké dělo ráže $30,5 \mathrm{~cm}$, zanechané po ústupu italské armády u městečka Zompicchia (30. ř́jen 1917).

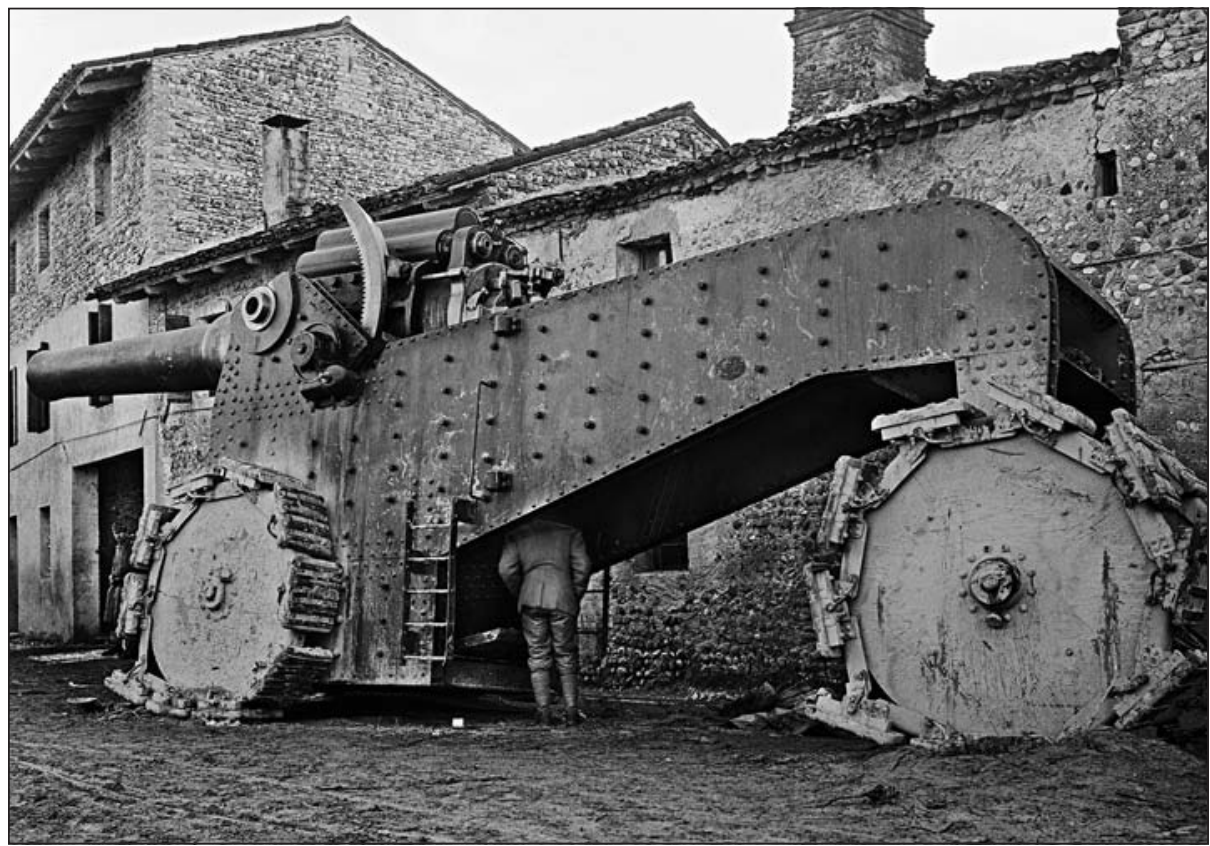


8. Pohled do zákopi̊ na Monte Asolone

(18. červenec 1918).

9. Improvizovaný lazaret $v$ Karpatech (1915).
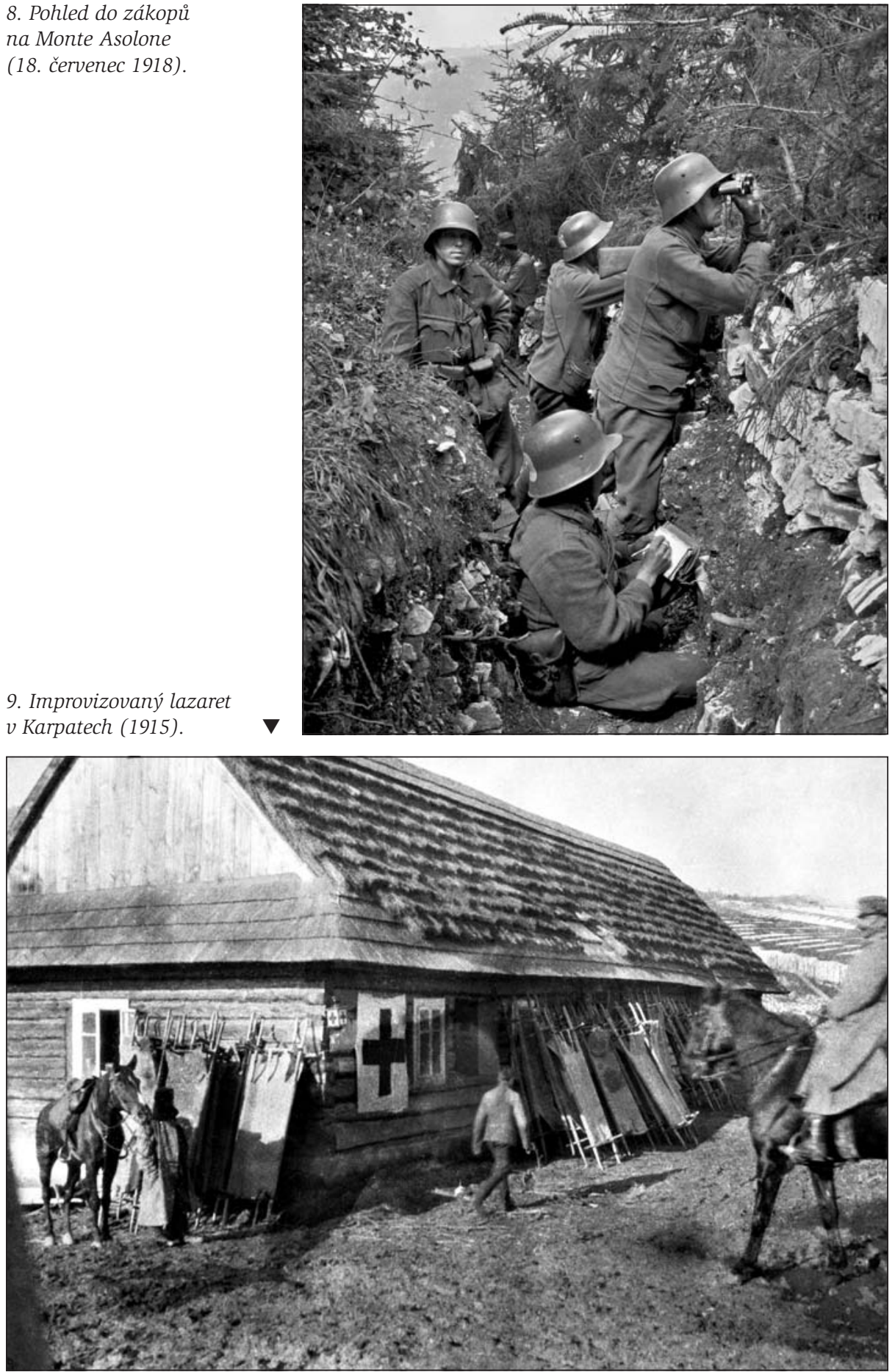


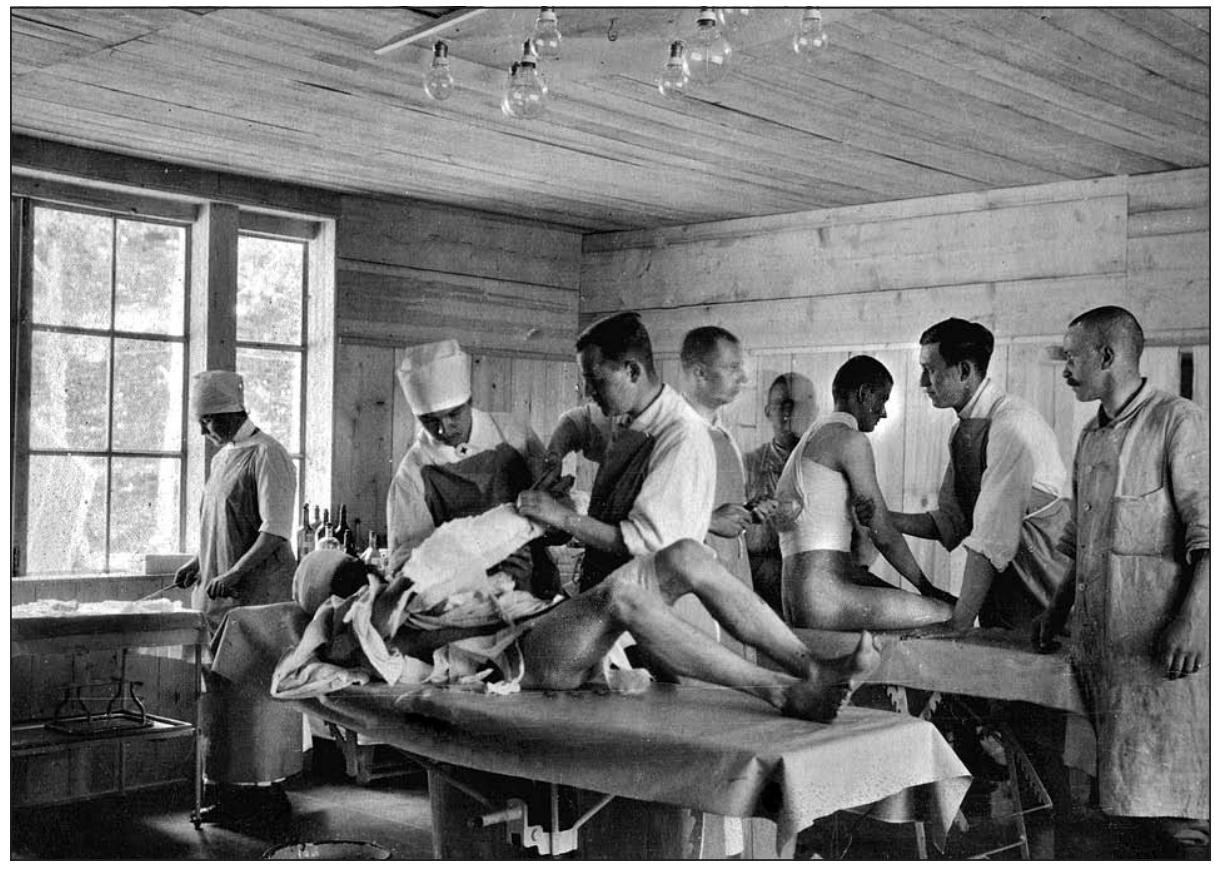

10. Operační zákrok v polním lazaretu.

\section{Rakousko-uherskou vojenskou stráží hlídaní italští zajatci při hygieně.}

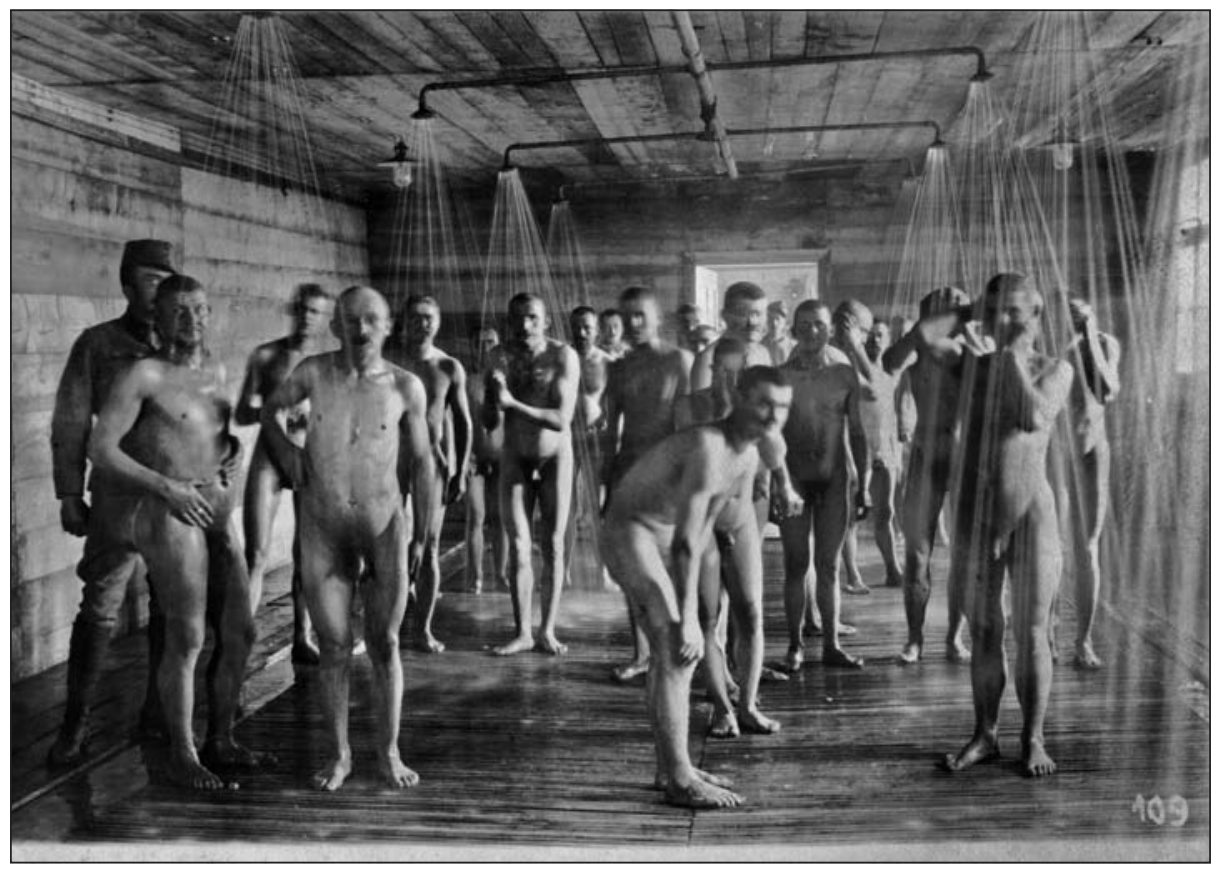




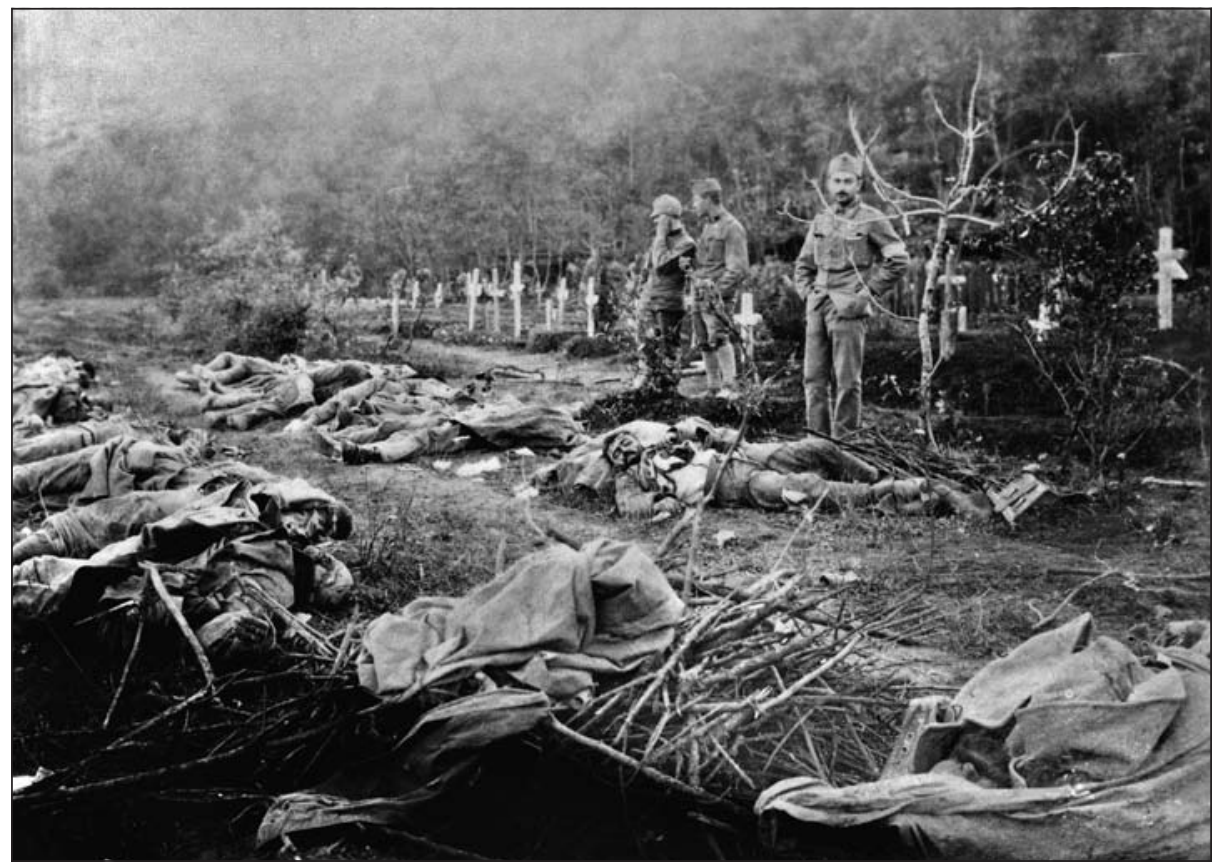

12. Padlí vojáci u Pietra Rossa, na kótě 85 u Monfalcone (22. ř́jen 1915).

13. Hrob padlého kamaráda Josefa Hlaváčka. Kras, Monte San Michele (5. leden 1916).

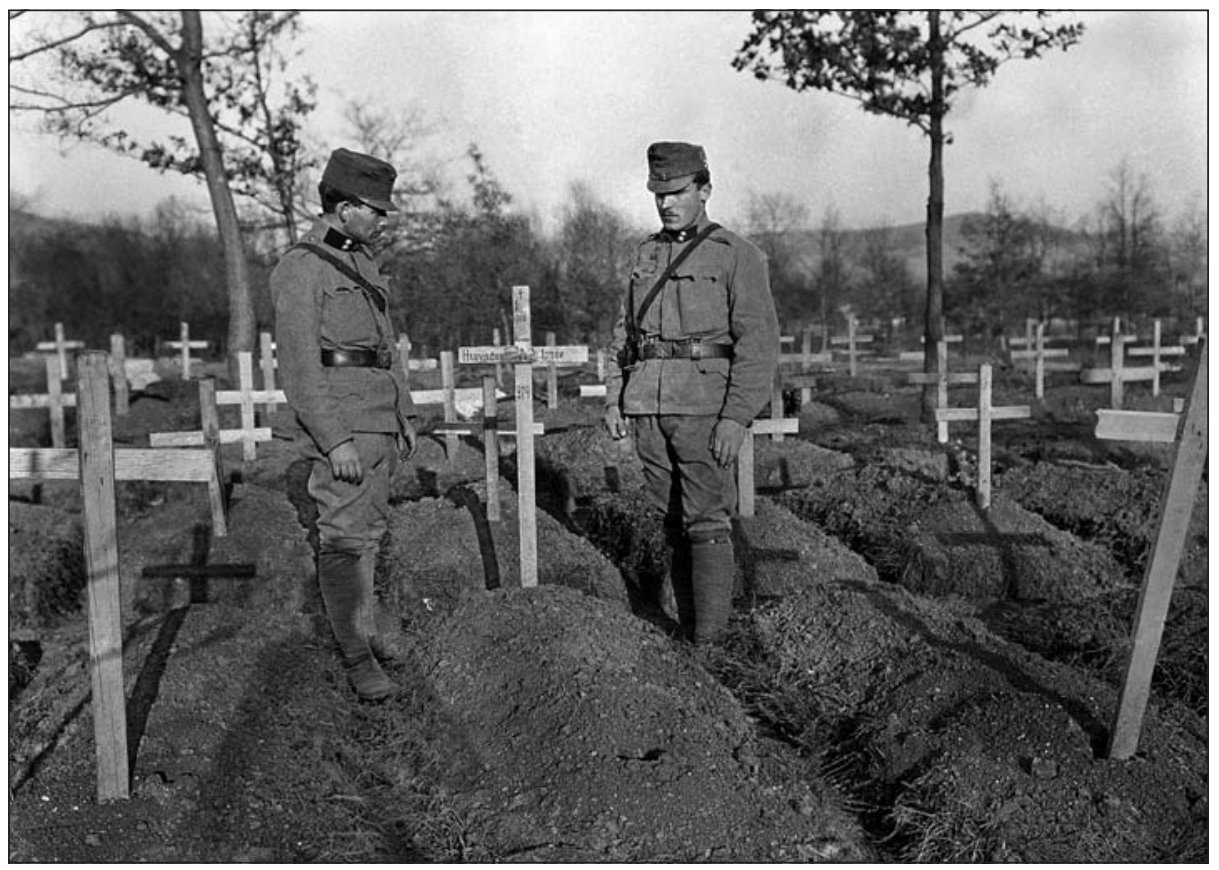




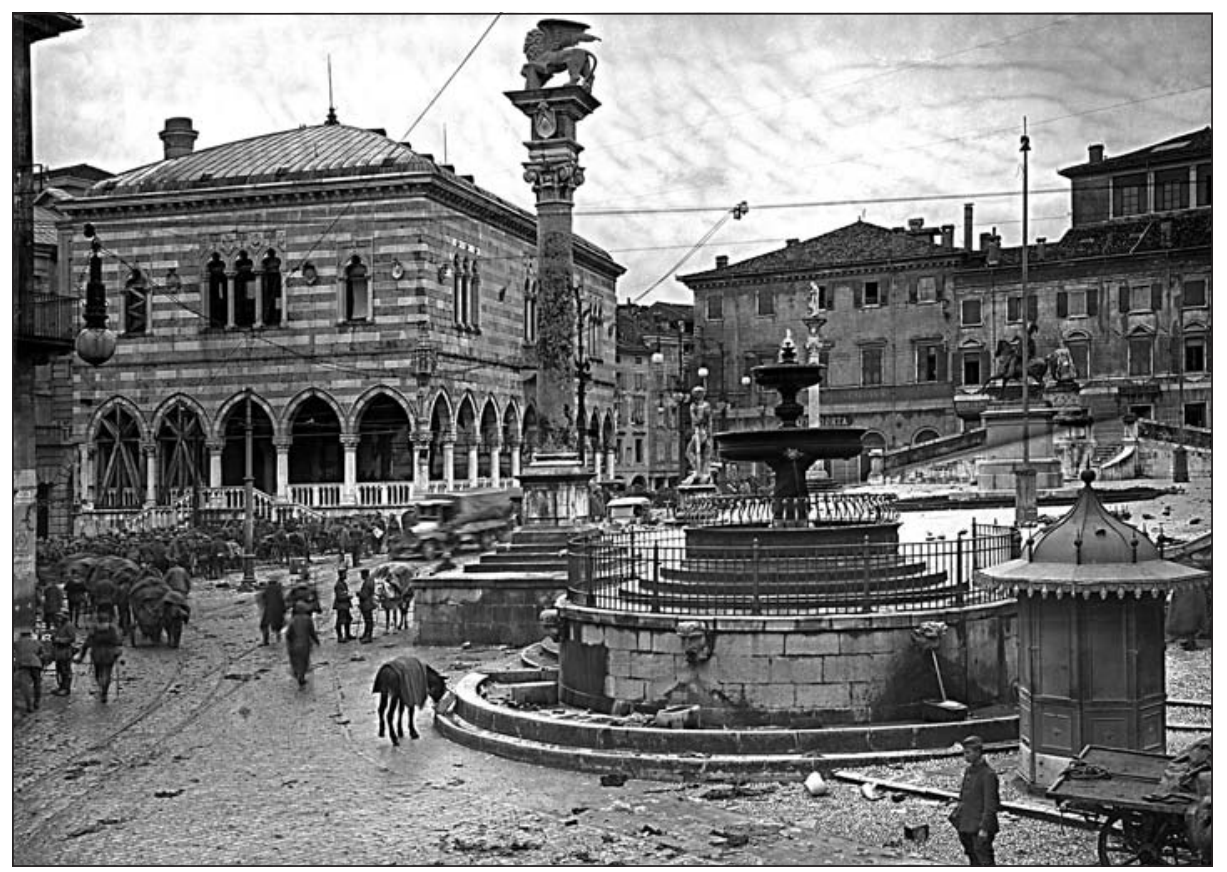

14. Udine, Piazza della Libertà po italském ústupu (ř́ijen 1917).

15. Konec automobilu 117. německého divizního velitelství po nehodè, na italskou armádou zničeném mostě přes řeku Meduna, východně od Pordenone (7. ř́jen 1917).

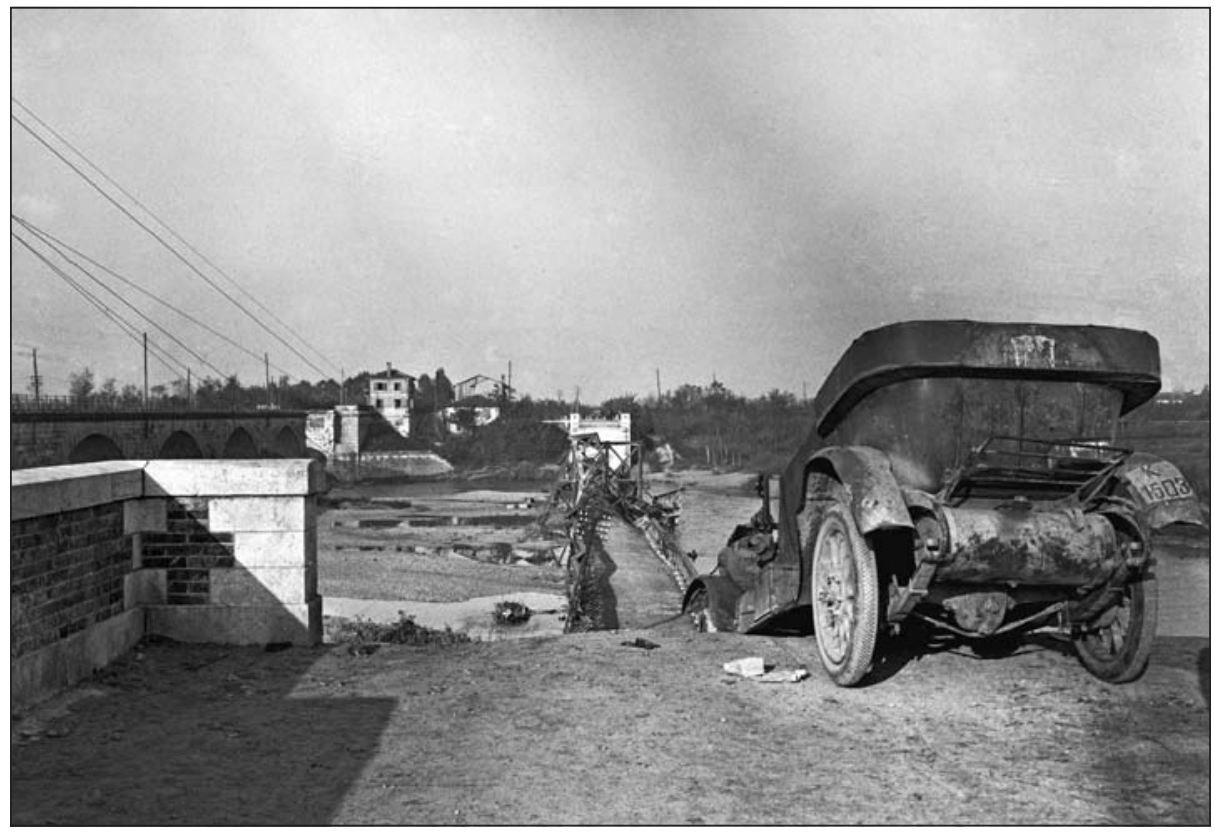


16. Stavba mostu pres ř́čku Monticano u Lutrana v Itálii (15. listopad 1917).

17. Parní pekárny v činnosti (únor 1918).
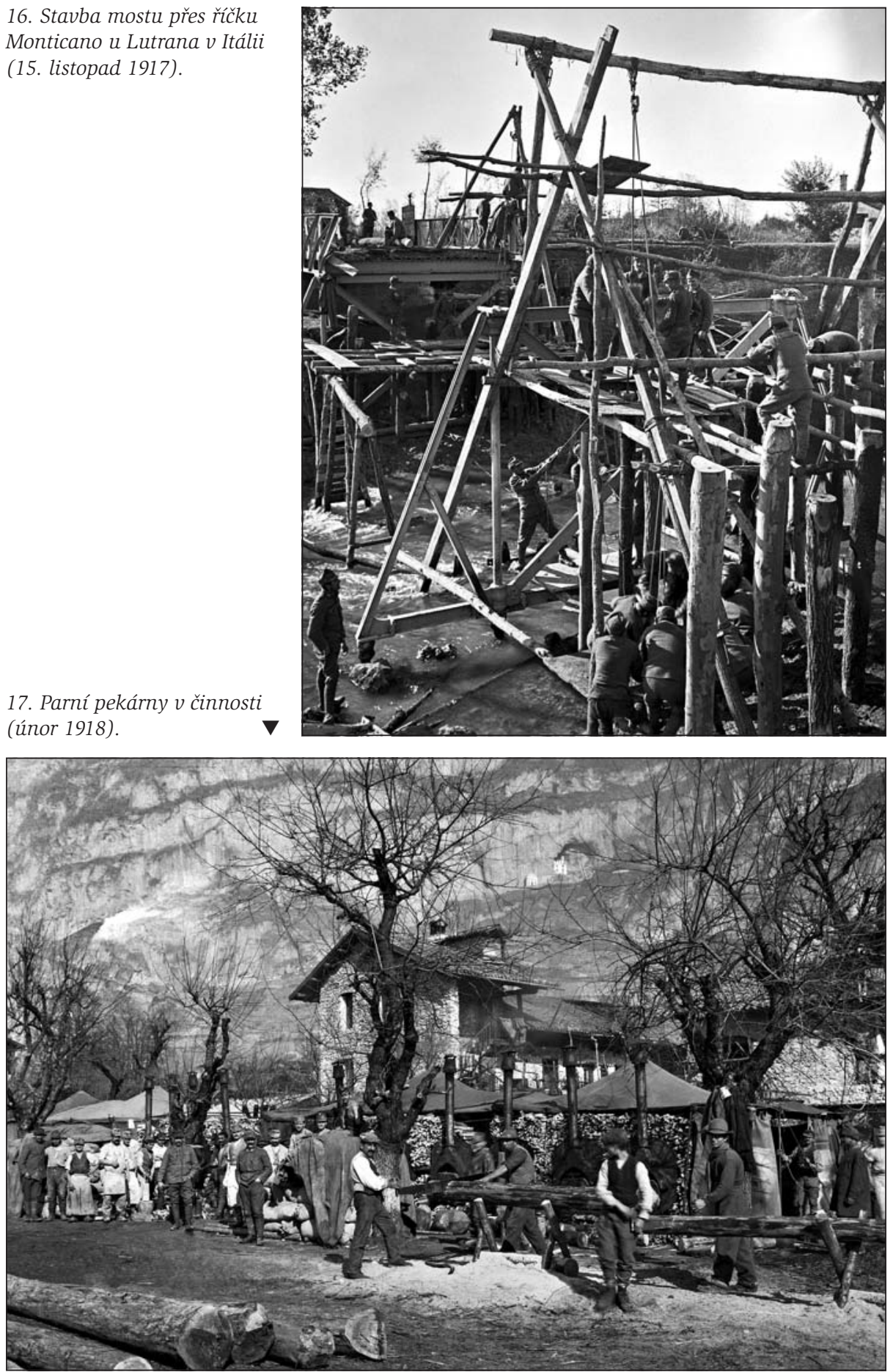


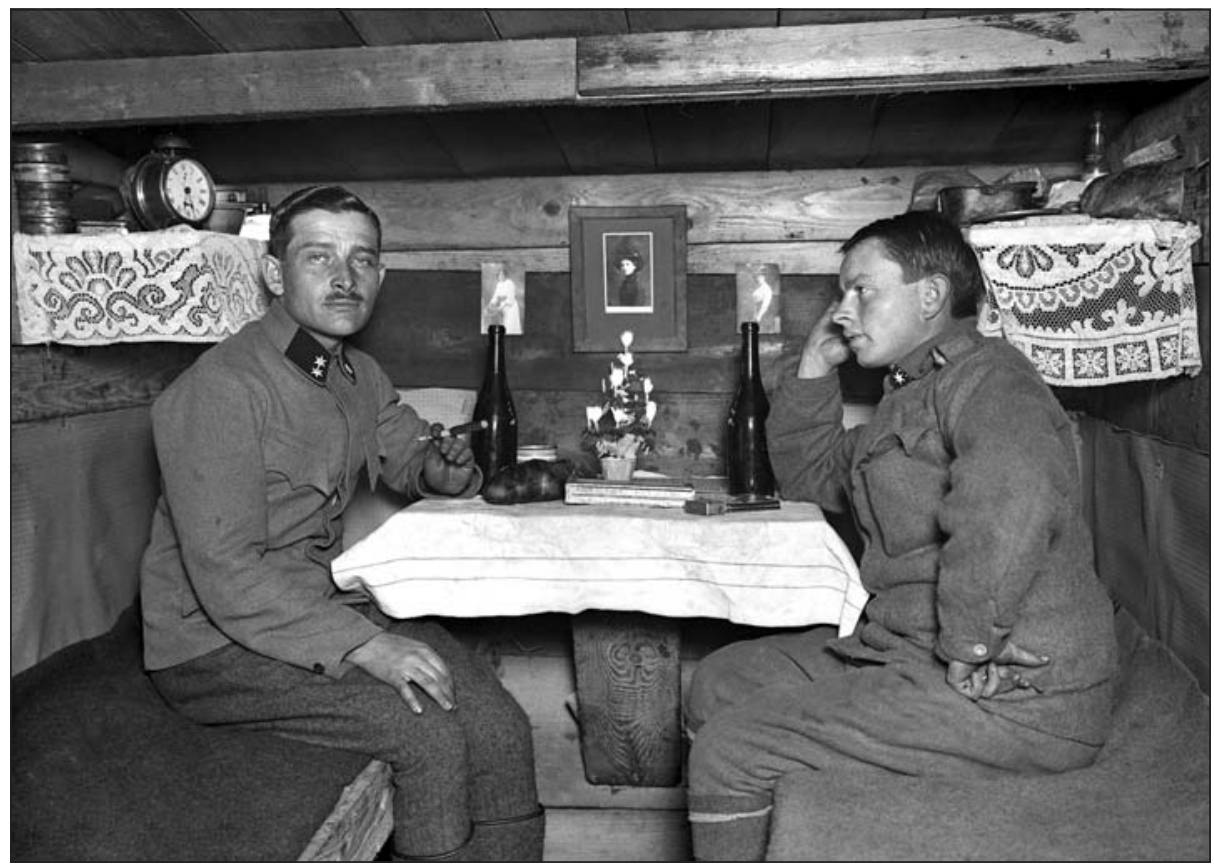

18. Štědrý večer v táboře Segeti (1915). Na snímku vlevo Jindřich Bišický, vpravo baron Ludwig von Vogelsang.

\section{Vaření jídla v Dolomitech (srpen 1918).}

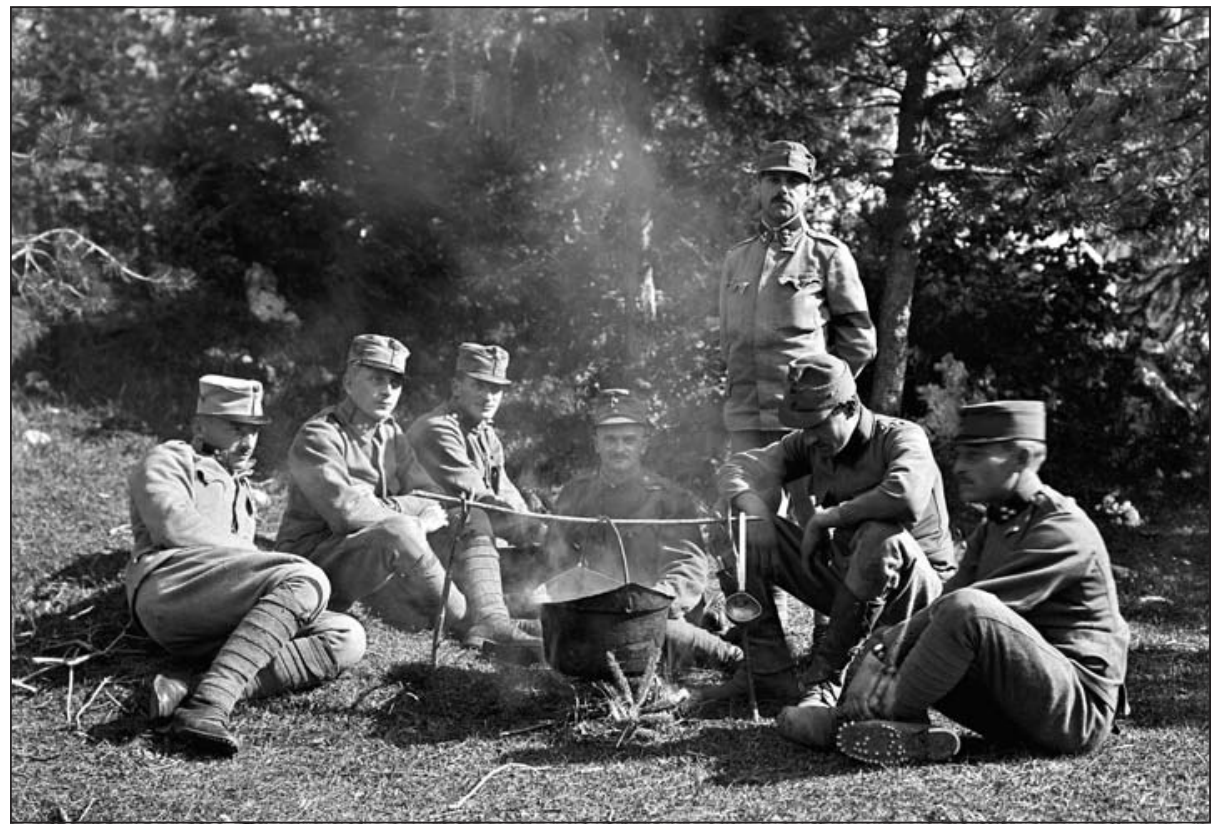




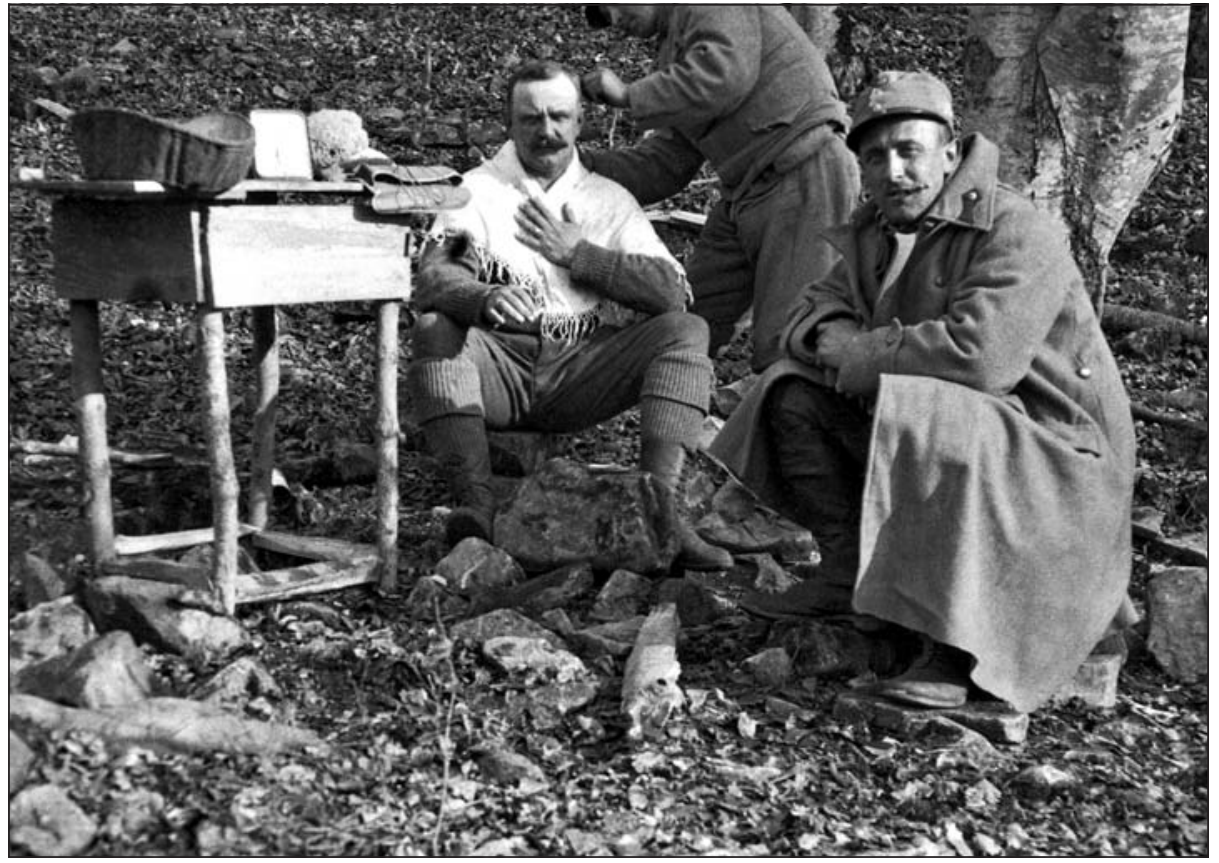

20. Každodenní život na frontě v Karpatech (1915).

21. Každodenní život na frontě v Karpatech (1915).

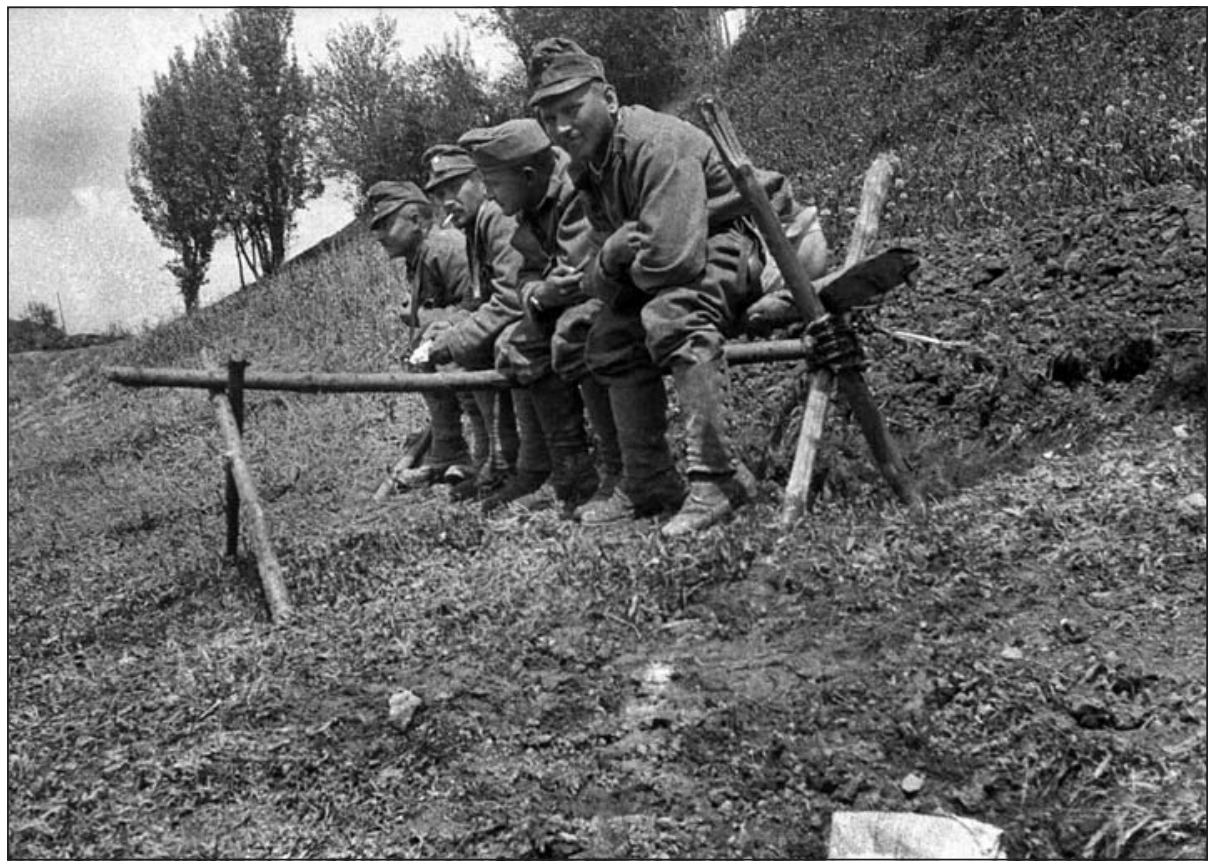




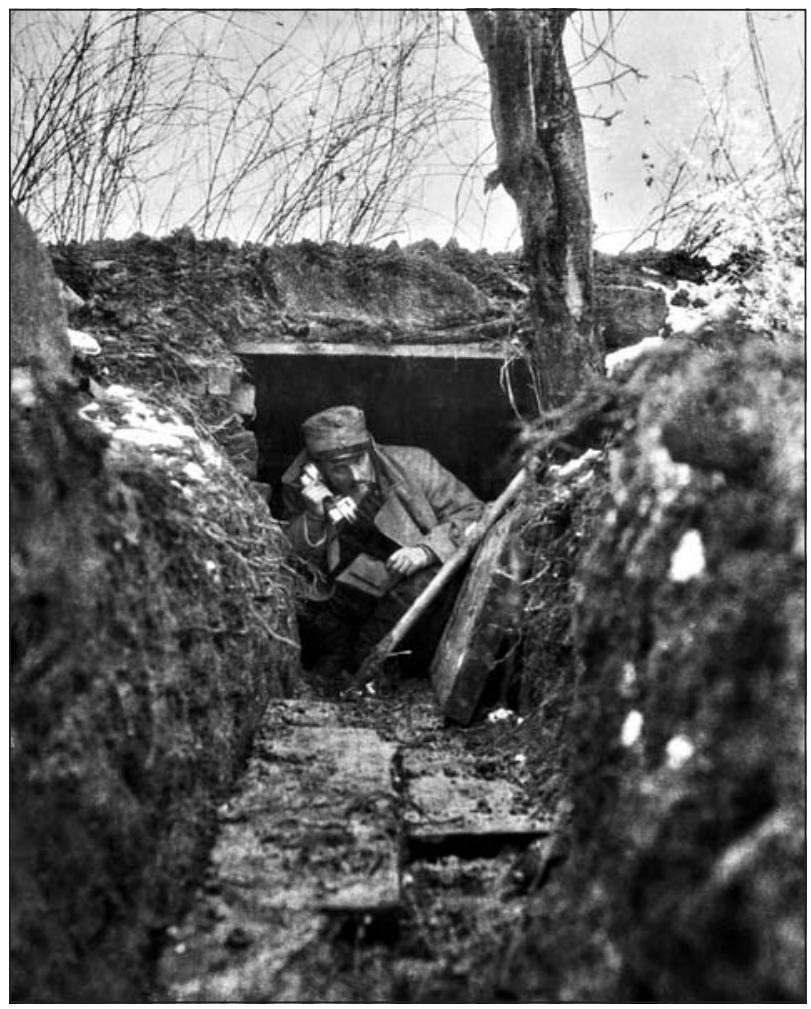

22. V zákopech při útoku u Sekovky v Karpatech (duben 1915).

23. Broušení bajonetů na brusu poháněném vodní silou, Karpaty (duben 1915).

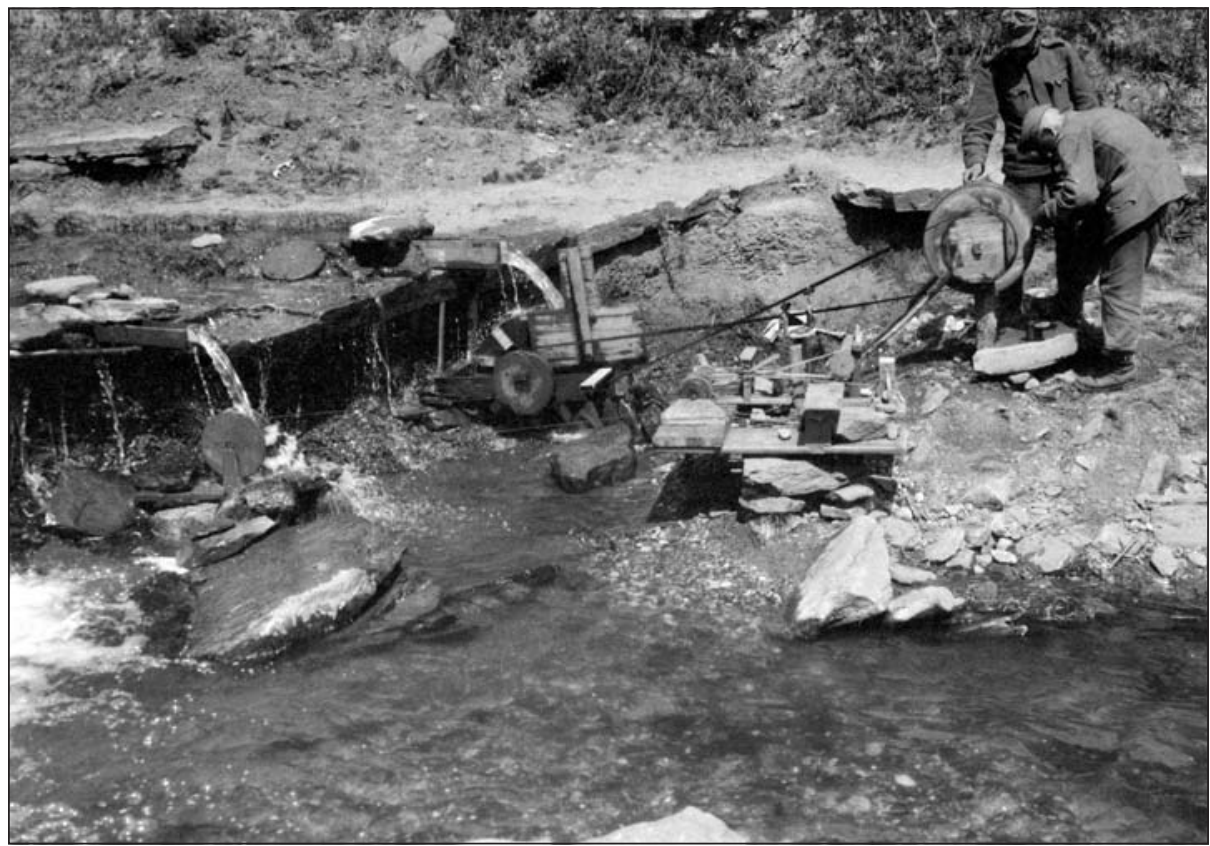


24. Židé v haličském

Delatynu (květen 1915).

25. Trh $v$ Kolomey $v$ Haliči (květen 1915).
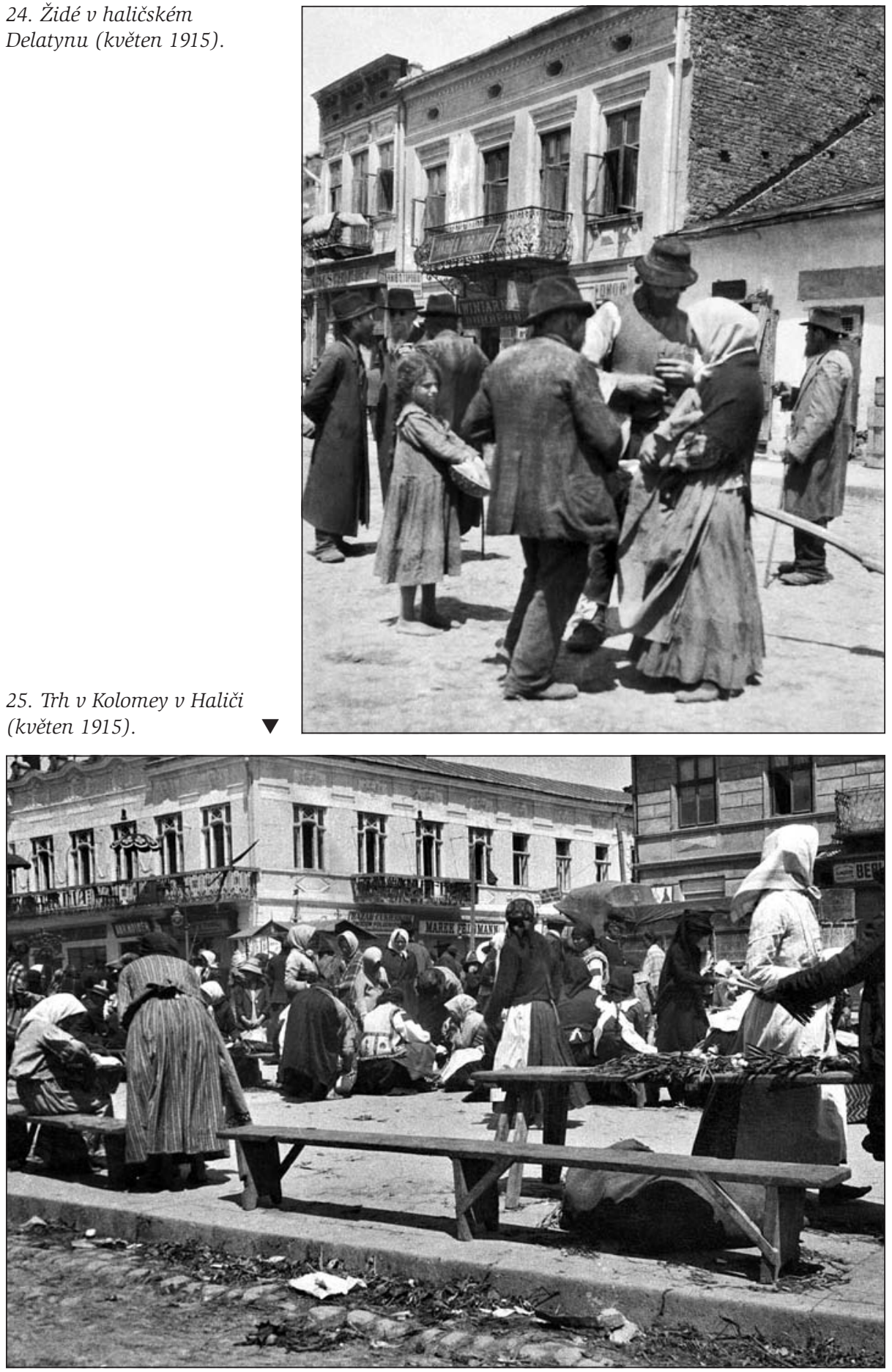


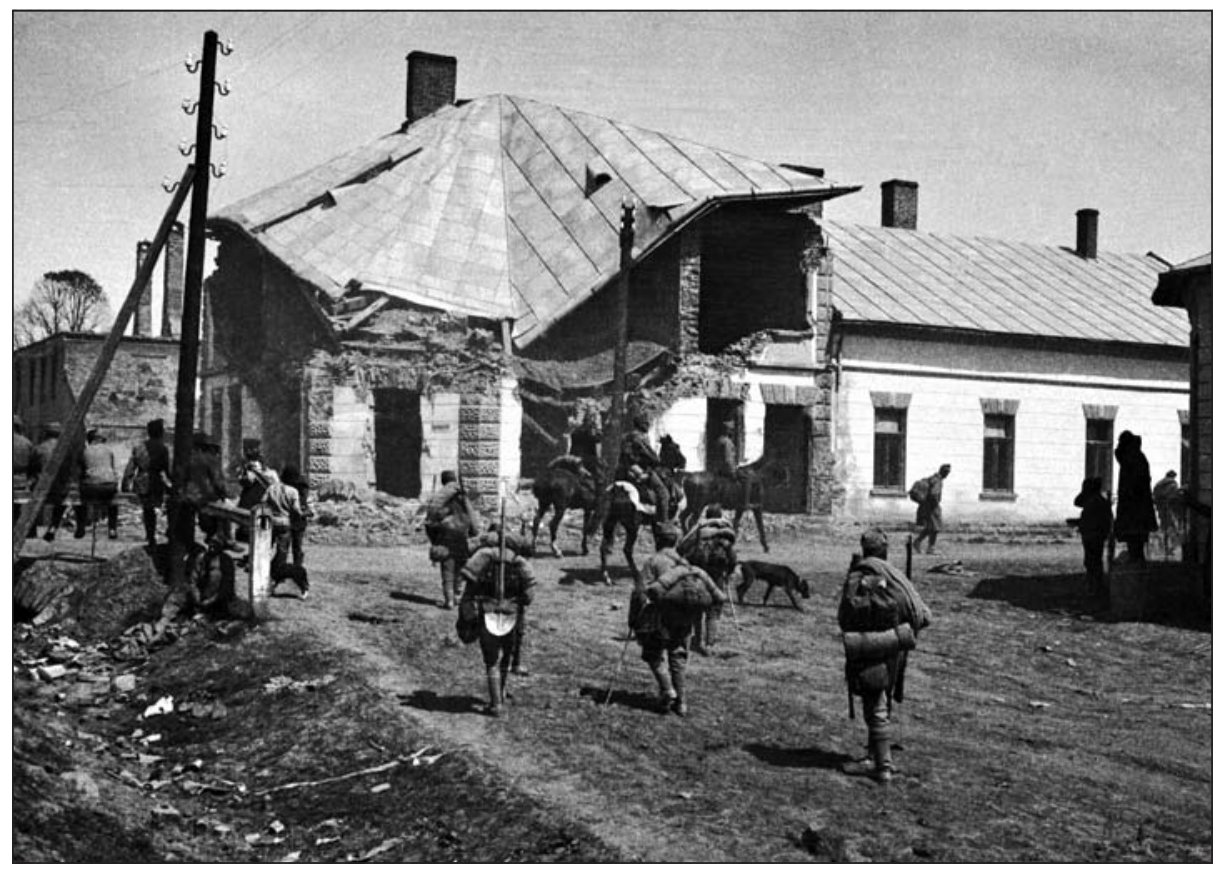

26. Zničená židovská čtvrt’ v Delatynu, Halič (červen 1915).

27. Stavba polní dráhy u Varama v Karpatech (květen 1915).

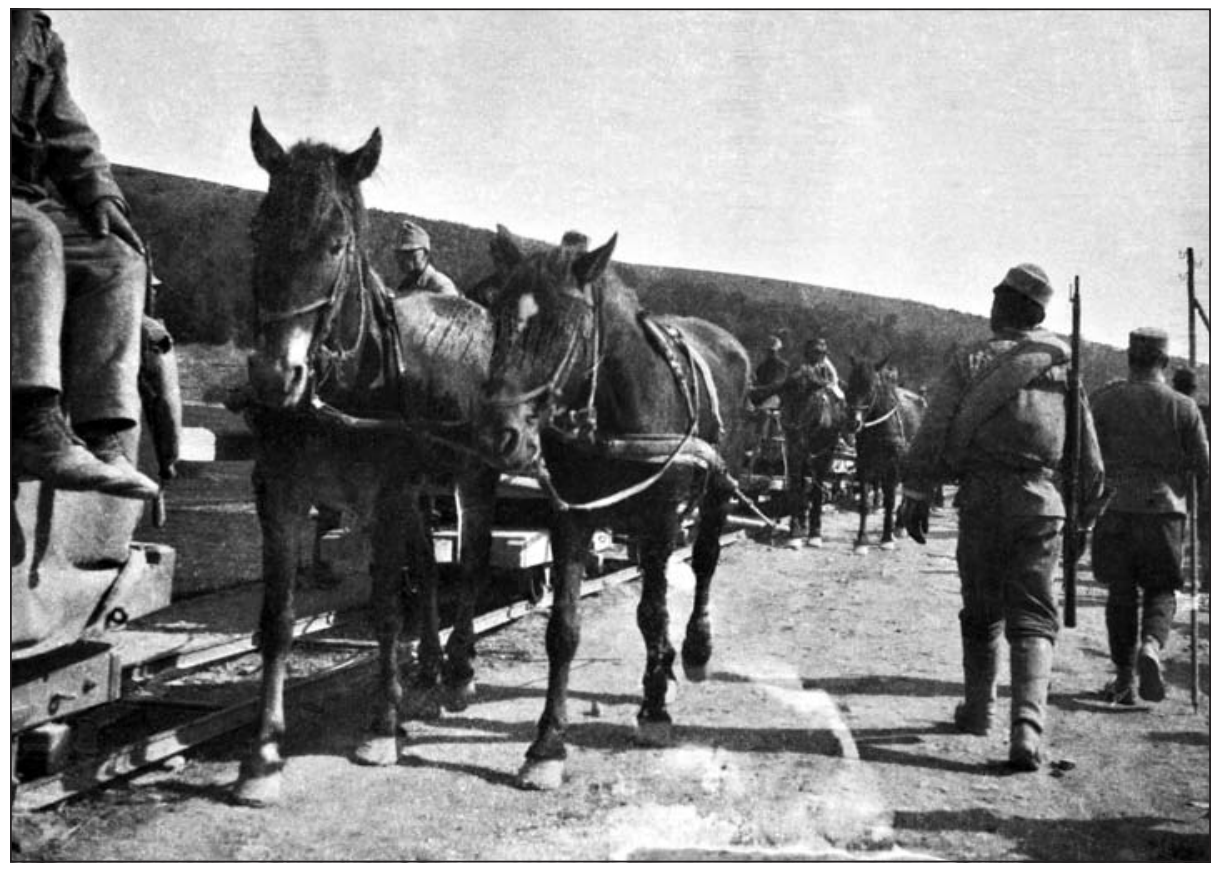




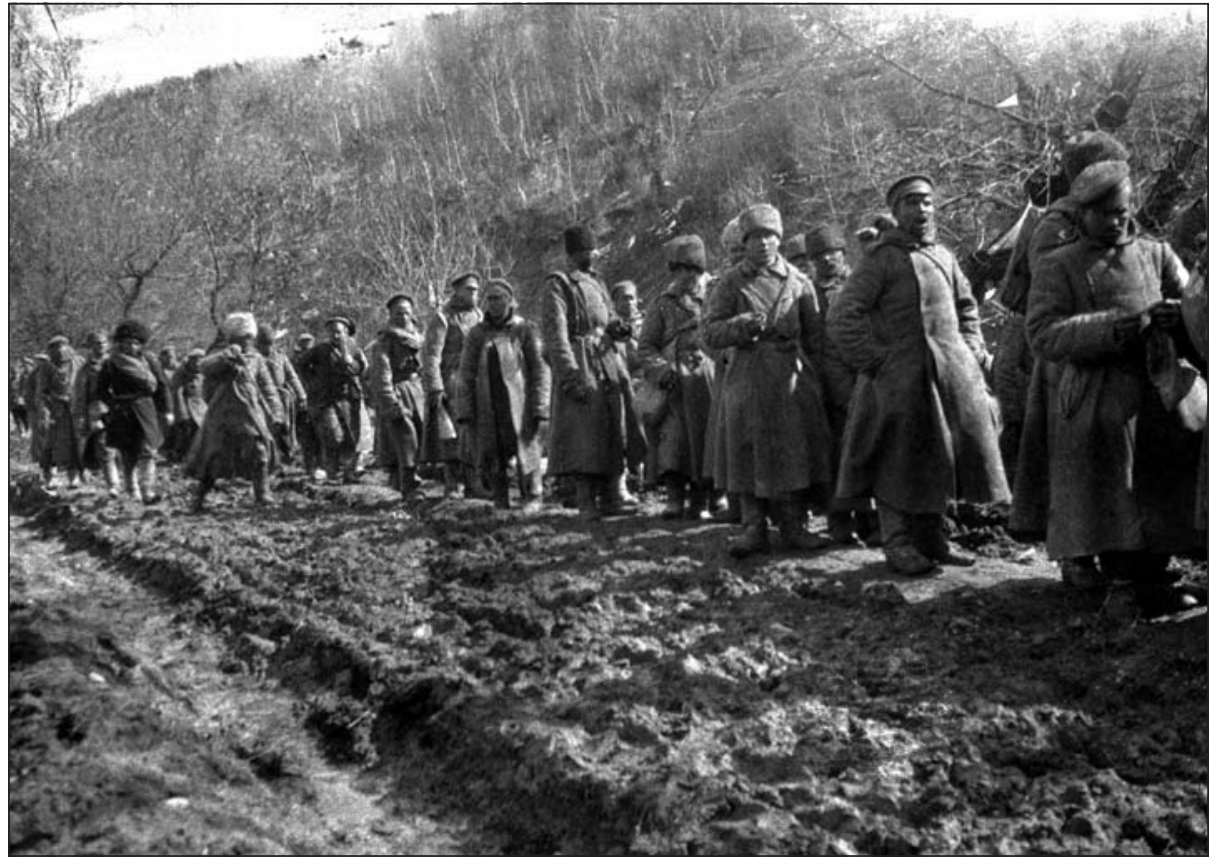

28. Zajatí ruští vojáci v Karpatech (1915).

29. Ruští zajatci přidělení na stavbu železnice v táboře Segeti v týlu sočské fronty (15. květen 1915).

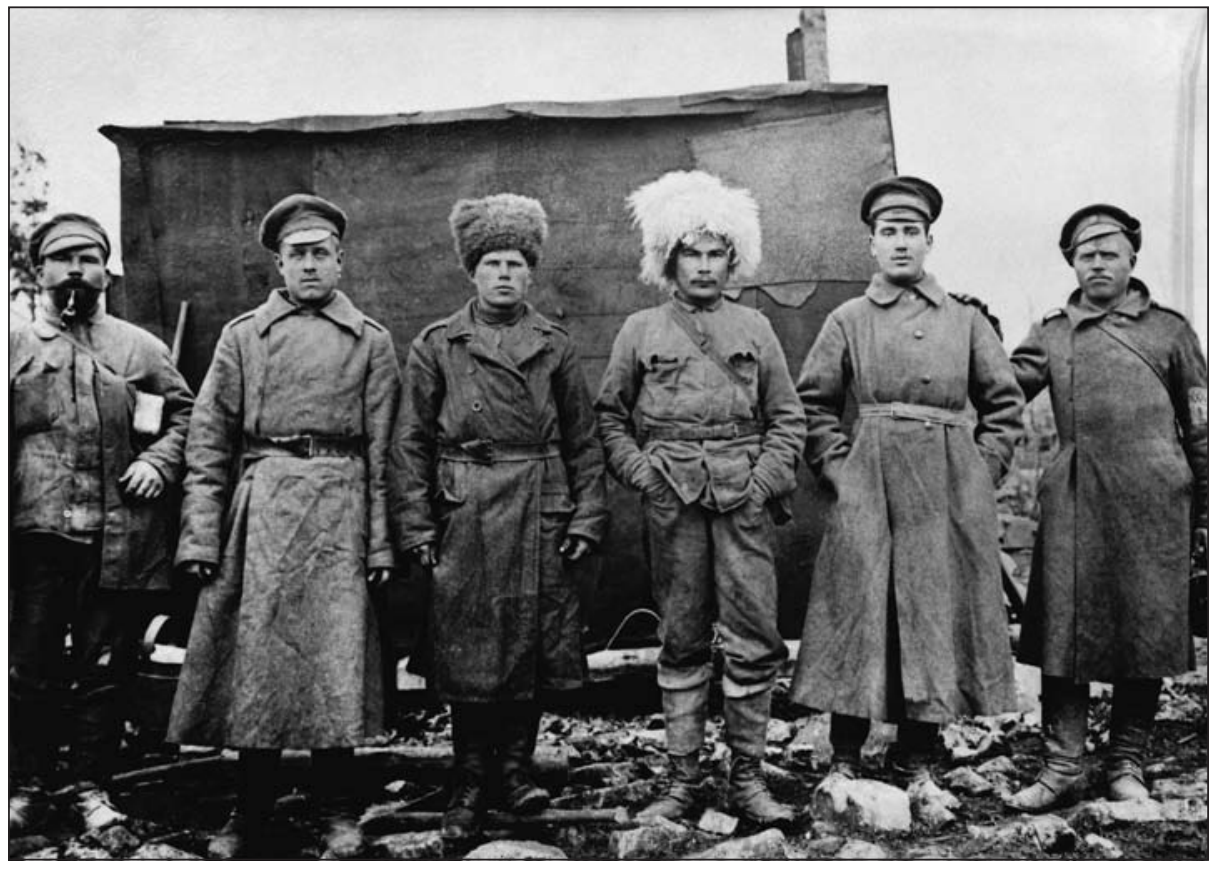

